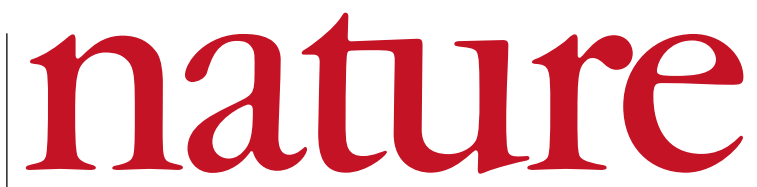

26 September 2002 Volume 419 Issue no 6905

\title{
Microarray standards at last
}

Not a moment too soon, the microarray community has issued guidelines that will make their data much more useful and accessible. Nature and the Nature research journals will respond accordingly.

Y ou read a paper with a fascinating conclusion about the expression of several genes. You decide to use some of the same experiments on your system of choice. But when you wade through hundreds of pages of supplementary information, you find that crucial details needed for replication are missing.

Welcome to the exciting but frustrating world of DNA microarray research. Microarrays are plastic or glass chips spotted with tiny amounts of thousands of probes, used to query the activity levels of that many genes in any tissue or organism at one time. Variables in every step of the experiment often make cross-paper comparison virtually impossible. Microarray papers also pose a considerable strain on the refereeing process; the vast amounts of data mean that critical review is a monumental task.

Yet referees sometimes feel they are not given enough details, leading cautious reviewers to think that they must reanalyse the primary data set. In other cases, the primary data provided are in proprietary software and so are impossible to comment on. Many journals allowed authors to put the huge data files on their own websites for the review process, until it became clear that unscrupulous authors compromised the anonymity of referees by tracking who had visited the website.

In a move to remedy these problems, the international Microarray Gene Expression Data (MGED) group has written an open letter to scientific journals proposing standards for publication. Other members of the microarray community welcomed these steps, designed to clarify the Minimal Information About a Microarray Experiment (MIAME) guidelines (Nature Genetics 29, 365-371;2001).
For authors, the proposal provides a checklist of variables that should be included in every microarray publication, at http://www. mged.org/Workgroups/MIAME/miame_checklist.html. This checklist, with all variables completed, would be supplied as supplementary information at the time of submission. The MGED group suggests that journals require submission of microarray data to either of two databases emerging as the main public repositories: GEO (www.ncbi. nlm.nih.gov/geo/) or ArrayExpress (www.ebi.ac.uk/arrayexpress).

Harried editors can rejoice that, at last, the community is taming the unruly beast that is microarray information. Therefore, all submissions to Nature and the Nature family of journals received on or after 1 December containing new microarray experiments must include the mailing of five compact disks to the editor. These disks should include necessary information compliant with the MIAME standard. The information must be supplied in a format that could be read by widely available software packages. Data integral to the paper's conclusions should be submitted to the ArrayExpress or GEO databases, with accession numbers where available, supplied at or before acceptance for publication.

How much data should authors provide to the community? Specifically, do other researchers really need to recreate the exact microarray just to test the expression level of a few key genes, which could presumably be done through other methods? Perhaps with further evolution and standardization of microarray technology, the need to specify so many variables will decrease, but the MGED standards are surely appropriate for the current state of the field.

\section{Dolly, Bikini and syncopated angst}

\section{A new piece of music theatre is an unusually direct appraisal of science's outcomes by two outstanding artists.}

magine four hands clapping in unison a fast syncopated rhythm that lasts just six quick beats. Repeat 12 times. Have one pair of hands shift the pattern in phase by half a beat, keeping the rhythm unaltered. The result to the listener is an emergent clapping pattern that is still fast and syncopated but quite different. Repeat 12 times, shift again, repeat, shift and so on until the original pattern re-emerges at the end of the cycle.

Clapping Music was written by Steve Reich in 1972, and represents the most distilled presentation of a style that he has embodied in many instrumental combinations. Requiring enormous concentration and skill from musicians, Reich typically deploys blocks of musical patterns of rhythm and harmony that unfold like a machine but are unpredictable and artistically judged, and can compel and delight any ear that has adapted to them. A true original, Reich has proved both popular and influential for the past 20 years.

Three Tales is Reich's latest excursion in this style. Completed in May, it is now on international tour (see www.stevereich.com) and will be produced as a DVD. But it is more than pure music that filled a large theatre in London for four nights last week. The work is a highly integrated combination of music with a video with soundtrack. It addresses explicitly the significance for humanity of technology — in particular, of the Hindenberg airship disaster, the Bikini Atoll test of the fission bomb, and Dolly the cloned sheep.

The video, by the pioneering video artist Beryl Korot (Reich's wife) takes images, newspaper cuttings and interviews of people involved in the events, and quotations from the Book of Genesis about responsibilities and power bestowed on mankind at the moment of creation. In the first section, the music ranges from keening harmonies in response to the Hindenberg explosion to a rhythmic rattle of metallic percussion for the airship's construction. The section about Dolly has biologists, artificial-intelligence researchers and ethicists commenting on cloning and identity. The emphasis of this movement is reflected by a statement by Richard Dawkins that: "We, and all other animals, are machines created by our genes”. Dawkins' impersonal visage uttering "machines" is seized on and looped seemingly endlessly.

This is genuine, compelling art that attracts lively and diverse audiences. It is a unique and morally ambiguous response to challenges whose origins lie in science. But it is built, in part, on soundbites that amount to a provocatively simplistic summary of what modern biology is telling us. Nevertheless, for those intrigued by a face-to-face encounter between outstanding music theatre and the implications of twentieth-century technology, this is a must-hear, must-see. 